\title{
The Role of Human Factor in the Innovation of Apricot Production-Empirical Study in a Disadvantage Area of East-Central European Country
}

\author{
Nagyné Demeter, D. ${ }^{1}$, Nyéki, J. ${ }^{2}$, Soltész, M. ${ }^{3}$ \& Szabó, Z. ${ }^{2}$ \\ ${ }^{1}$ Károly Róbert College, Institute of Agroinformatics and Rural Development, H-3200 Gyöngyös, Mátrai str. 36. \\ ${ }^{2}$ University of Debrecen, Centre of Agricultural Sciences and Engineering, Faculty of Agricultural and Food \\ Sciences and Environmental Management, H-4032 Debrecen, Böszörményi str. 138. \\ ${ }^{3}$ Collage of Kecskemét, Faculty of Horticulture, H-6000 Kecskemét, Erdei Ferenc tér 1-3.
}

\begin{abstract}
Summary: Hungary is a traditional fruit growing country for ages. As fruit sector has a very high hand work request and value added, it has an important role to decrease the elimination of unemployment and the lack of income in the disadvantage rural areas. The study was made in the year of 2009, the studied population consisted of the members of the fruit-grower marketing organization (Gyümölcsért Ltd.), that organizes growing and sales of stone fruits in Hungary. The number of studied population were 95 capita, the number of filled out and evaluated questionnaires was 35. By the composition of the questions both qualitative and quantitative methods have been used. We tried to get answers to the following questions: Are the studied human factors (age, educational level, sex etc.) of growers, determined the extension of innovation of apricot production?
\end{abstract}

Key words: apricot variety use, questionnaire survey, human factor

\section{Introduction}

During our research, we intended to explore the characteristics of the apricot plantations of the Gönc production area, the knowledge and practice of farmers concerning variety use, their future changes and its specific reasons. Besides this, our aim was to gather the qualitative and quantitative information necessary for the development of consultancy and the research guidelines. Therefore, the basic objective of the study is to put together a comprehensive situation report that supports the identification and reinterpretation of the problems in the variety use in this production area, as well as the solutions to these problems. It is important to emphasise that this current examination is a "situation report", therefore, it cannot describe the temporal changes of the explored phenomena (Nagyné Demeter et al., 2010 a). So, this current study intends to represent one part of this comprehensive research. We wish to briefly

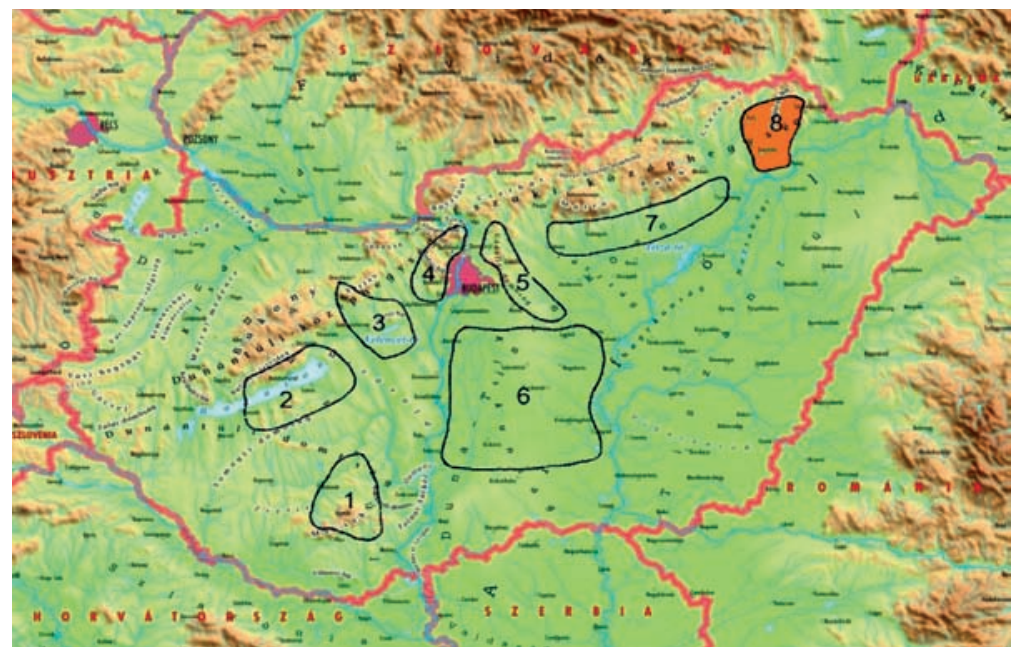

Source: Self edited based on Pénzes-Szalay, 2003

Figure 1. The sample area

1. Mecsek production area, 2.Balaton production area, 3. Velence lake production area, 4. Buda production area, 5. Pest-Gödöllő production area, 6. Duna-Tisza production area, 7. MátraBükkalja production area, 8. Gönc production area-Sample area introduce mainly the research results concerning the role of human factor in the innovation, in this case variety use, of apricot production use.

\section{Methods}

The Gönc production area is the sample area of examination (Figure 1). The quantity of apricot produced in the examined sample area is significant even on the national level. Based on the data of the Agricultural Register (ÁMÖ), 22.2\% of the net area of the Hungarian apricot plantations is constituted by the Gönc production area that is located in BorsodAbaúj-Zemplén County. Therefore, this production area has a high importance in the Hungarian apricot production, this is why the survey and evaluation of the variety use that basically determines the success of production could serve as a guideline even on the national level, mainly in the issues of variety use, variety switch and the acquisition and use of information about varieties. The issues of variety selection 
strongly depend on the production site endowments of each production area, therefore, research results often describe the characteristics of the given sample area. Nevertheless, in cases when we examined the role of human capital, the results could serve as a guideline even on the national level. In order to be able to fully support these issues, similar survey of the other production areas and the comparison of results per production area are also needed.The growers, who filled the questionnaire, were selected random simple sample. Two data collection were used during our research work: primer and secondary data collection. The resources of the primer data-collection were the questionnaires of our empirical survey that have been completed by the relevant information from informal interviews with farmers (who previously filled the questionnaires in).

We introduced and analysed the local (county level) and the wider (region level) farming conditions by the secondary data. By the composition of the questions both qualitative and quantitative methods have been used. We used frequency test among descriptive statistics methods, within that the relative and cumulative distribution of variables of a given problem were evaluated and represented. In case of multiple answers the analysis was made by frequency and cross tables upon the previously defined multiple answer groups and sets (Babbie, 2001). The collected data were evaluated by the software SPSS 13.0 for Windows to find the right answers to our questions; beside this the figures were made by Microsoft Office Excel 2003, while the maps by the computer program GeoMedia Professional 5.1.

\section{Results and discussion}

Regarding the distribution between different agecategories of the in the research work involved people a relative high homogeneity could be observed. The average age of the involved people was 44.14 years, the mean was 45 years. The value of average age and the median was near to each other. So the distribution of age-categories are showed normal distribution. The value of standard deviation was law (St. Dev.=11.7), too (Figure 2.).

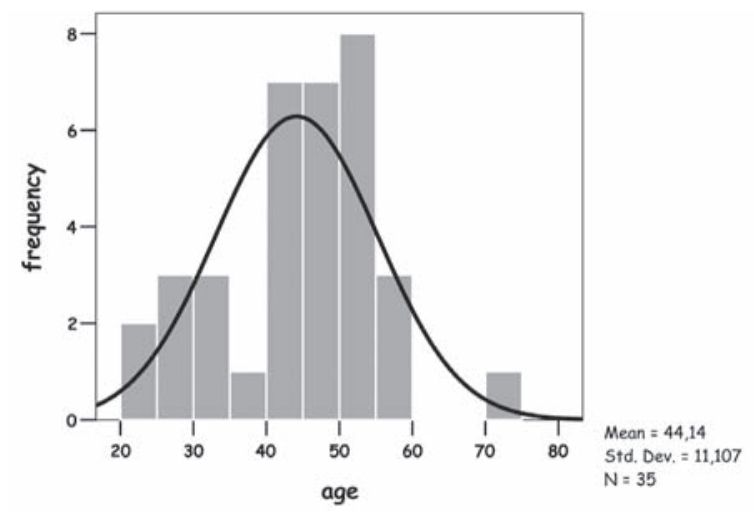

Source: On the basis of empirical research, self-edited.

Figure 2. The distribution of involved answerers between different age-groups, regarding the frequency of the valid answers, 2009
The sex distribution of involved people reflects the national and county conditions as well. $85.7 \%$ of the involved people are men (national rate: $86 \%$ ), while only $14.3 \%$ are women (national rate: $14 \%$ ). This fact lets us conclude that although farming is present in women's lives, still they lead a farm rather rarely. In most of the cases they are represented as assisting or employed labour in the production. Regarding the farming period, $51.4 \%$ of answerers have been dealing with apricot production for more than ten years. $37.1 \%$ have been farming for 5-10 years. It can give us a favourable basis for the evaluation of questions in connection with the investigation of farmers' opinion and reactions. Regarding the farming character, mainly fruit growers have been asked. The most part of these growers don't deal with other agricultural production. The reason for that was mainly that questions in connection with fruit growing had a significant role in the survey that motivated us to have our questionnaires filled in at forums and training courses. Regarding the education of farmers it can be stated that rate of the answerers have a secondary school education and the rate of the answerers have a higher education degree equivalent $(28.6 \%)$. The second largest group (25.7\%) has secondary technical school and $2.9 \%$ has only basic skills. This value is favourable than the regional and county data. This indirectly shows that in this large value added and labour intensive sector must the growers have up-to-date production knowledge. Because of it, without these knowledge they could not manage their farms. This favourable phenomenon due to the average age of the involved people was 44 years, and the involved answerers belong to the age group 60 or older were very low. As well as the most part of growers is market-oriented.

Referring to the farming state the population consisted mostly of part-time growers $(54.3 \%)$, then the full-time growers $(40 \%)$, and $5.7 \%$ of the sampling population is pensioner. The examination of the factors affecting farmers' variety use had a high priority in the study. The generally held view that the innovative skills of the farmers are weak and that they rather stick to their production traditions instead of market-focused farming is not true in this case. It can be seen from the answers that the farmers in the production area mainly prefer competitiveness (Figure 3 ) in variety use (Nagyné Demeter et al., 2010 b).

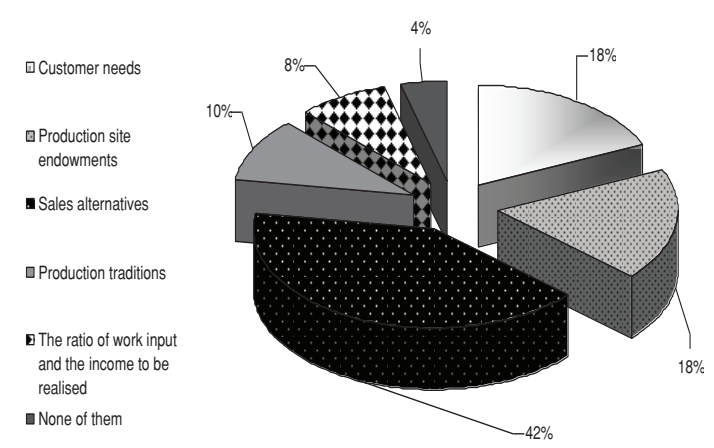

Source: On the basis of empirical research, self-edited.

Figure 3. Distribution of determinate of used nectarin species, in the distribution (\%) of valid answers, 2009 
Nevertheless, there are many occasions when this preference does not prevail in practice. As it will be seen later, the probable reason for this phenomenon is the lack of information and capital, instead of the frequently mentioned problems with mentality. It can be seen in the figure that variety use is mainly affected by sales alternatives, customer needs and production site endowments. The priorities that farmers considered to be the most important ones well reflect the fact that apricot production in the production area is governed by the market. Based on the results of the correlation analyses, the answers given are proportionate among the educational levels of the respondents, therefore, the educational level does not determine the variety use of farms among the interviewees (Figure 4).

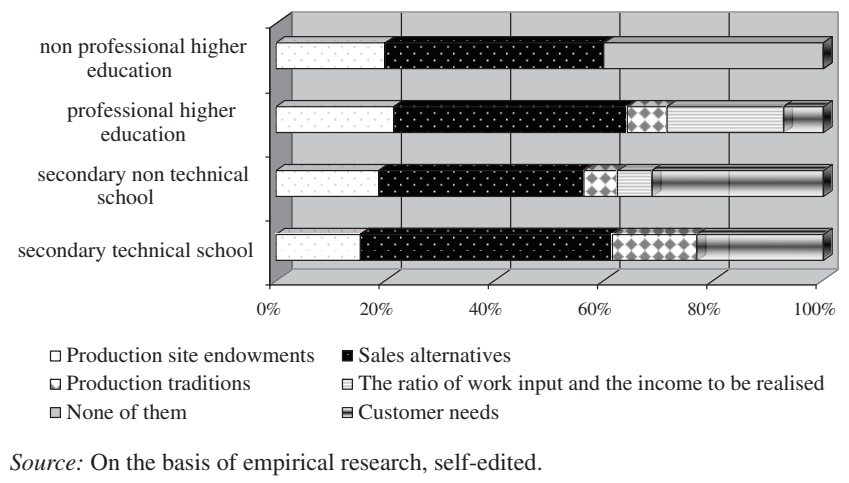

Figure 4. Correlation between educational level and variety use, in the distribution (\%) of valid answers, 2009

We carried out correlation analysis in order to more accurately explore the reasons for the extension of variety use. Based on these correlation analyses, there is no statistical correlation between the ages of the farmers and the factors affecting variety use $(\mathrm{p}=0.22)$ neither as a function of the number of workers, the ratio of income from fruit production $(\mathrm{p}=0.28)$, nor the time spent with farming so far $(\mathrm{p}=0.21)$. Causes of lack of modern species in Hungary were also studied. Neither using of modern species $(p=0.64)$ nor causes of using of them $(\mathrm{p}=0.61)$ were not affected by education level. Consequently, the lack of modern species is due to the lack of capital and information.

During our research work we search the correlation between educational level and information of variety use.

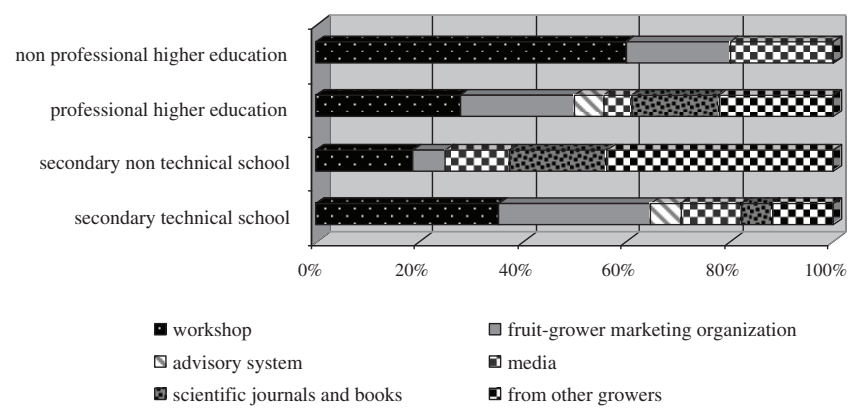

Source: On the basis of empirical research, self-edited.

Figure 5. Correlation between educational level and information of variety use, in the distribution (\%) of valid answers, 2009
The combination of information source is constricted as a function of education level (Figure 5.). The advisory system is represented by very law value. This fact call the attention to the lack of advisory system in the horticultural sector.

The answers are well proportioned in the group of professional higher education. It's very important that between the educational level of growers and the useful of information were not correlation $(\mathrm{p}=0.33)$. In the case of information utilization was the results of correlation analyses same $(p=0.57)$.

\section{Conclusion}

Our results pointed out that the hungarian scientific establishment Alvincz, J. and Varga, T. (2000).: Situation of family farms and possibilities for the improvement of their competitiveness; Kaproncai I. (ed.) (2005): Characterisation of farmers' adaptability - The answers of farmers to actual questions; Alvincz, J. (ed.) (2003): The income-situation of agriculture and the affecting factors; The taxing of the incomes of individual agricultural producers;] as the spread of marketable technologies are hindered by the low educational level and agronomic knowledge offarmers is false. We found that production experience is the strength of Hungarian growers to compensate their incomplete information. Only 2.9 percent of growers answered that the information source was satisfactory and suitable. Nearly 30 percent of growers gave the answer that the information sources were not useful and suitable. From this, they had several problems at planting and production of a new apricot variety.

\section{Acknowledgements}

Thanks to TECH_08-A3/2-2008-0373 and TECH_08A4/2- 2008-0138 projects for financial assistance.

\section{References}

General Agricultural Register (2000): Központi Statisztikai Hivatal, Budapest. II. kötet. 254. (in Hungarian)

Babbie, E. (2001): A társadalomtudományi kutatás gyakorlata. Balassi Kiadó, Budapest. 564. (in Hungarian)

Nagyné Demeter, D. Nyéki, J., Soltész M., Szabó Z. (2010a): Examination of the apricot variety use and the factors affecting variety use in the Gönc production area. International Journal of Horticultural Science, 2010/3.

Nagyné Demeter, D. Nyéki, J., Soltész, M., Szabó, Z., (2010b): Termelői szerveződések müködése a Gönci-termőtájon., Agriculture and Countryside in the Squeeze of Climate Change and Recession. Hódmezővásárhely, 2010. április 22. 89-94.

Alvincz, J., Varga, T. (2000): A családi gazdaságok helyzete, versenyképességük javításának lehetőségei. Agrárgazdasági Kutató és Informatikai Intézet 2000/15. 86. (in Hungarian)

Alvincz, J.(ed.) (2003): A mezőgazdaság jövedelemhelyzete és az arra ható tényezők. Budapest, Agrárgazdasági Kutató és Informatikai Intézet.2001/7. 7-11. (in Hungarian)

Kapronczai, I. (ed.) (2005): A mezőgazdasági termelők alkalmazkodóképességének jellemzői (Gazdálkodói válaszok időszerü kérdésekre). - Agrárgazdasági Tanulmányok. 2005/6 sz. Budapest, Agrárgazdasági Kutató és Informatikai Intézet. 89. (in Hungarian) 